\title{
Arte Social em Moana Nui, Aotearoa
}

$O$ artista John Vea, que vive em Tāmaki Makaurau (Auckland), trabalha com escultura, vídeo e performance. Possui um mestrado em arte e design na Universidade de Tecnologia de Auckland (2015), onde atualmente desenvolve doutorado. Vea trabalha com tropos de migração e gentrificação em Moana Nui a Kiwa. Ao encenar histórias que foram coletadas por meio de interações cotidianas com pessoas, tanto em sua comunidade local quanto no exterior, ele oferece, com uma sensibilidade jornalística, um ponto de vista êmico, às vezes humorístico e sempre poderosamente simbólico, à meta-narrativa ocidental. <john.j.vea@gmail.com> ORCID: 0000-0001-6515-6012

Dr. Chris Braddock é professor de Artes Visuais na Universidade de Tecnologia de Auckland (AUT). Co-lidera o Ph.D. e M. Phil. e o Art \& Performance Research Group. Supervisiona uma série de práticas de projeto de doutorado. É autor de Performing Contagious Bodies: Ritual Participation in Contemporary Art (Palgrave Macmillan, 2013) e editor de Animismo em Arte e Performance (Palgrave Macmillan, 2017) explorando conhecimento Māori e não-indígena correspondentes aos termos 'animismo' e 'quem' ou "o que" é creditado como animação.<chris.braddock@aut.ac.nz> ORCID: 0000-0002-4751-0636
Resumo Este artigo discute metodologias emergentes nas práticas artísticas performáticas Moana Nui a Kiwa (MNak) (Pasific ${ }^{1}$ Peoples) em Aotearo ${ }^{2} a$, New Zealand (NZ). Explora maneiras nas quais a pesquisa artística orienta questões e resultados finais de investigação dentro do contexto de uma prática de doutorado. Os métodos de pesquisa de John Vea (Tonga / NZ) fazem referência ao trabalho de Timote Vaioleti sobre "talanoa" (1996) como uma noção MNak sobre o respeito em encontros com as pessoas. A prática de desempenho de Vea envolve grupos minoritários do MNak - explorando tropos de migração e subseqüente interação com a hegemonia - nas quais "cooperações" com grupos e pequenos grupos desafiam alguns modelos tradicionais de pesquisa de liderança e autoria. Essas abordagens indígenas encorajam uma leitura diferente de teóricos, como Chantel Mouffe e suas idéias de navegação no ativismo artístico e espaços agonísticos de cooperação compartilhada.

Palavras-chave Coletivos, Cooperação, Agonista, Moana Nui a Kiwa, talanoa. 


\section{Moana Nui Social Art Practices in Aotearoa}

Tāmaki Makaurau (Auckland) based artist John Vea works with sculpture, video and performance art. John gained a Master of Art and Design at Auckland University of Technology in 2015, where he is currently undertaking his practice led Ph.D. Vea works with tropes of migration and gentrification within Moana Nui a Kiwa. By enacting stories that have been collected through everyday interactions with people, both in his home community and abroad, with a journalistic sensibility he offers a sometimes humorous and always powerfully symbolic emic viewpoint to the Western meta narrative.<john.j.vea@gmail.com> ORCID: 0000-0001-6515-6012

Dr Chris Braddock is Professor of visual arts at Auckland University of Technology (AUT). He co-leads the Ph.D. and M.Phil. programmes and the Art \& Performance Research Group. He supervises a range of practice led $\mathrm{PhD}$ projects. He is author of Performing Contagious Bodies: Ritual Participation in Contemporary Art (Palgrave Macmillan, 2013) and editor of Animism in Art and Performance (Palgrave Macmillan, 2017) exploring Māori and non-indigenous scholarship corresponding with the term 'animism' and 'who' or 'what' is credited with animacy. <chris.braddock@aut.ac.nz> ORCID: 0000-0002-4751-0636
Abstract This article discusses emerging methodologies in Moana Nui a Kiwa (MNak) (Pasific Peoples) performance art practices in Aotearoa New Zealand (NZ). It explores the ways in which artistic research guides research questions and final research outputs within the context of a practice led PhD degree. John Vea's (Tonga/NZ) underlying research methods reference Timote Vaioleti's work on 'talanoa' as a MNak notion about respectfulness in personal encounters with people. Vea's performance practice engages with MNak minority groups - exploring tropes of migration and subsequent interaction with hegemony - where 'co-operations' with collectives and small groups challenge some traditional research models of leadership and authorship. These indigenous approaches encourage a different reading of theorists such as Chantel Mouffe and her ideas of navigating artistic activism and agonistic spaces of shared cooperation.

Keywords Collectives, Cooperation, Agonistic, Moana Nui a Kiwa, talanoa. 


\section{Introdução}

Metodologias de pesquisa emergentes para Moana Nui a Kiwa (MNak) (Pasífic Peoples) em Aotearoa, Nova Zelândia (NZ), desafiam abordagens, protocolos e ética de pesquisa hegemônicas e muitas vezes institucionalizadas. As maneiras MNak de fazer pesquisas (ou seja, as maneiras pelas quais interagimos com os chamados grupos focais e como formulamos perguntas ou conversas que queremos ter com elas) tendem a privilegiar decisões coletivas em vez de indivíduos, e colocam menos ênfase na importância de resultados racionais ou confiáveis. Timote Vaioleti explora "talanoa" como uma noção MNak que orienta os processos de pesquisa coletiva apropriados a fim de "preservar a integridade de todos os participantes da pesquisa" (2006: 32). Como as abordagens do MNak se relacionam com teóricos proeminentes, como Chantel Mouffe e suas idéias de navegação no ativismo artístico e espaços agonísticos de cooperação compartilhada? Exploramos o ativismo artístico de Mouffe com foco particular em John Vea como ativista artístico. Como sua pesquisa cooperativa em arte pode orientar questões e resultados de pesquisa (dentro do contexto de uma prática de doutorado)?

Encontramos pontos de convergência tentadores entre as idéias de Vaioleti e Mouffe. Por exemplo, Mouffe insiste em desbancar o conceito do artista como um indivíduo de vanguarda único e privilegiado cujo gênio criativo oferece uma crítica

\section{Introduction}

Emerging research methodologies for Moana Nui a Kiwa (MNak) (Pasific Peoples) in Aotearoa New Zealand (NZ) challenge hegemonic and often institutionalised research approaches, protocols and ethics. MNak ways of going about research (i.e., the ways in which we interact with socalled study groups of people and how we formulate questions or conversations we want to have with them) tend to privilege collective decisions rather than individuals, and place less emphasis on the importance of rational or reliable outcomes. Timote Vaioleti explores 'talanoa' as an MNak notion that guides appropriate collective research processes in order to "preserve the integrity of all participants in the research". ${ }^{15}$ How do MNak approaches relate to prominent theorists such as Chantel Mouffe and her ideas of navigating artistic activism and agonistic spaces of shared cooperation? We explore Mouffe's artistic activism with particular focus on John Vea as art activist. How might his cooperative artistic research guide research questions and outputs (within the context of a practice led PhD degree)?

We find tantalising points of convergence between the ideas of Vaioleti and Mouffe. For example, Mouffe insists on debunking the concept of the artist as a unique and privileged avant-garde individual whose creative 
decisiva sobre a sociedade. Sua ênfase em grupos ativistas de arte coletiva (que também corresponde à abordagem artística de John Vea) tem algo em comum com o destaque de Vaioleti aos processos coletivos dos povos do Pacífico como comunidades em Aotearoa, na Nova Zelândia. Esses processos coletivos típicos da metodologia de pesquisa talanoa minam a confiabilidade e consistência nos resultados da pesquisa (Vaioleti, 2006: 32) e isso tem muito em comum com as idéias aparentemente paradoxais de Mouffe sobre uma democracia antagônica na qual as lutas e diferenças devem permanecer visíveis e na qual as formas de reconciliação racional são impossíveis e deliberadamente descartadas (ver Mouffe, 2007: 3).

Há também diferenças entre as idéias de Vaioleti e Mouffe dificeis de conciliar. Por exemplo, talanoa parece ter ambições de harmonia coletiva que Mouffe poderia resistir em favor de seu conceito de espaço público como um campo de batalha onde diferentes projetos de hegemonia se confrontam sem a necessidade de reconciliação (Mouffe, 2007: 3). Mas pode ser possível que as formas MNak de pesquisa ofereçam outras maneiras de interpretar as idéias de Mouffe sobre políticas democráticas antagônicas $(2007: 3,5)$.

Nós não chegamos a nenhuma conclusão. A prática da escrita em si levanta questões, motivadas pelos trabalhos de prática e narrativa. Como será visto, uma metodologia de pesquisa talanoa cria um mapa composto das histórias das pessoas; suas

genius delivers a decisive critique on society. Her emphasis on collective art activist groups (which also corresponds with John Vea's artistic approach) has something in common with Vaioleti's emphasis on the collective processes of Pacific peoples as communities in Aotearoa NZ. These collective processes typical of talanoa research methodology undermine reliability and consistency in research results ${ }^{16}$ and this has quite a lot in common with Mouffe's seemingly paradoxical ideas about an antagonistic democracy in which struggles and differences must remain visible and where forms of rational reconciliation are impossible and deliberately jettisoned. ${ }^{17}$

There are also differences between the ideas of Vaioleti and Mouffe that we find difficult to reconcile. For example, talanoa seems to harbour ambitions for collective harmony that Mouffe might resist in favour of her concept of public space as a battleground where different hegemony projects confront each other without a need for reconciliation. ${ }^{18}$ But it might be possible that the MNak ways of going about research offer other ways of interpreting Mouffe's ideas of adversarial democratic politics. ${ }^{19}$

We don't come to any tidy conclusions. The practice of writing itself raises questions, prompted by the labours of practice and storytelling. As will be seen, a research methodology of talanoa creates a compound map of peoples' stories; their concerns, their realities and desires. A 
preocupações, suas realidades e desejos. Uma relação de dar e receber entre "prática e escrita / escrita e prática" gradativamente percorre o projeto ou a tese. Mas essa relação é às vezes torturante e a natureza da prática artística pode ser evocativa e até mesmo perturbadora. Como uma exegese (componente escrito) opera em relação à prática artística que resiste a resultados racionais ou mesmo confiáveis?

Exploraremos as obras coletivas e cooperativas de John Vea, One Kiosk Many Exchanges, como parte do projeto grupal Share / Cheat / Unite, de 13 de agosto a 23 de outubro de 2016 (curada por Bruce E. Phillips, Te Tuhi, Auckland) e sua Instalação Aloha 'Aina Fonua para a inauguração da Bienal de Honolulu, no Havaí, 2017. Múltiplos intercâmbios por meio de narrativas e redes de colaboradores resultam em pesquisas artísticas que não poderiam ter sido pré-planejadas ou previstas. Também vamos discutir Mo'ui Tukuhausia, 2012, uma performance do artista tonganês / neozelandês Kalisolaite "Uhila" na Te Tuhi Gallery, em Auckland.

give-and-take relationship between 'practice and writing/writing and practice' gradually percolates through the project or thesis. But this relationship is sometimes torturous and the nature of artistic practice can be evocative and even disturbing. How does an exegesis (written component) operate in relation to artistic practice that resists rational or even reliable outcomes?

We will explore John Vea's collective and cooperative artworks One Kiosk Many Exchanges as part of the group project Share/Cheat/Unite, 13 August - 23 October 2016 (an offsite commission curated by Bruce E. Phillips, Te Tuhi, Auckland) and his 'Aloha 'Aina Fonua installation for the inaugural Honolulu Biennial in Hawaii, 2017. Multiple exchanges through storytelling and networks of collaborators result in artistic research that could not have been pre-planned or foreseen. We will also discuss 'Mo'ui Tukuhausia, 2012, a performance by Tongan/New Zealand artist Kalisolaite 'Uhila at Te Tuhi Gallery, Auckland. 


\section{Edgewalkers Pasifika}

Quando eu era criança, meus pais migraram de Tonga para Aotearoa NZ no início dos anos 1980. Eu descobri no meu primeiro dia de escola primária que tinha duas culturas para me relacionar. Até aquele dia, a única que eu realmente conhecia era 'anga fakatonga; a cultura de Tonga e, subsequentemente, a educação que meus pais me deram. E, ironicamente, minha segunda cultura aotearoana que agora me influenciou também permeou o lugar do meu nascimento. Eu comparo isso com estar no limbo, mas não no senso comum da palavra - perdido e caótico - mas no sentido de ter a habilidade de experimentar duas culturas. Relaciono isso com o ponto de vista de um médium ou de uma pessoa que afirma estar em contato com os espíritos dos mortos e capaz de se comunicar entre os mortos e os vivos. No meu caso, tenho dois espaços e negocio entre os dois do ponto de vista do limbo.

Anne-Marie Tupuola usa o termo " $\mathrm{Pa}$ sifika edgewalkers para tentar dar sentido "aos caminhos como os jovens de segunda e terceira geração de descendente do Pacífico / Oceania na Nova Zelândia / Aotearoa podem estar alcançando seu status de identidade" (2004) : np). Questiona a relevância "das teorias de identidade 'indígenas' e 'nativas' ao pesquisar ou trabalhar com jovens de identidades múltiplas e transitórias" e encoraja "estudiosos e educadores do Pacífico a ir além da categorização da juventude do Pacífico dentro de parâmetros rígidos" porque "jovens estão cruzando culturas e adotando identificações distantes de sua genealogia e geografia local "(Tupuola, 2004: np).

\section{Pasifika Edgewalkers}

\begin{abstract}
When I was a child, both my parents migrated to Aotearoa NZ from Tonga in the early 1980s. I figured out on my first day of primary school that I had two cultures to relate to. Until that day, the only one I really knew was 'anga fakatonga; the Tongan culture and subsequent upbringing my parents gave me. And, ironically, my second Aotearoan culture that now influenced me also permeated the place of my birth. I compare this to being in limbo, but not in the common sense of the word - lost and chaotic - but in the sense of having an ability to experience two cultures. I relate this to the point of view of a medium or a person claiming to be in contact with the spirits of the dead and able to communicate between the dead and the living. In my case I have two living spaces and I negotiate between the two from the limbo perspective. $^{20}$
\end{abstract}

Anne-Marie Tupuola uses the term 'Pasifika edgewalkers' as she tries to make sense "of the ways second and third generation youth of Pacific/Oceanic descent in New Zealand/Aotearoa may be reaching their achieved identity status, if at all". ${ }^{21}$ She questions the relevance "of 'indigenous' and 'native' theories of identity when researching or working with youth of transient and multiple identities" and encourages "Pacific scholars and educators to move beyond the categorisation of Pacific youth within rigid parameters" because "youth are crossing between cultures and adopting identifications far removed from their genealogy and local geography".22 
Como uma das muitas crianças MNak, na escola, muitas vezes éramos chamadas de ilhéus pelas crianças Māori e Palangi e alguns professores usavam vagamente essa expressão também. O termo se referia a pessoas das ilhas do Pacífico que viviam em Aotearoa; foi usado para sugerir que éramos forasteiros ou como ouvi dizer: "você é tonganês, você não é daqui (Aotearoa)". Em minha primeira visita à terra natal de meus pais, Tonga, tive uma experiência semelhante com a família e os habitantes locais me chamando de tamasi'i muli, que se traduz em menino - estrangeiro ou estrangeiro. Essa foi a minha experiência de crescer; o resultado de outros nos posicionando em uma cultura deslocada. Eu não me importei com esses termos deslocados. Mas, quando crianças, pensávamos que era normal, sermos chamados de forasteiros e não fazer parte desse lugar e não importando em que lugar estivéssemos. ${ }^{3}$

Por meio de eventos sociais que são coordenados de forma cooperativa, a prática artística de John é envolvida com a experiência dos edgewalkers de Pasifika como um estado de limbo, entendido como uma experiência de duas ou mais culturas. Os métodos de pesquisa da Talanoa privilegiam parâmetros menos rígidos, encorajando processos de contar histórias em camadas co-construídas.

\footnotetext{
As one of many MNak kids at school, we were often called Islanders by the Māori and Palangi children and some teachers would loosely use this expression also. The term Islanders referred to people who were from the Pacific Islands living in Aotearoa; it was used to suggest we were outsiders or as I heard it said, "you're Tongan Islander, you're not from here (Aotearoa)". My first time visiting my parents' homeland Tonga, I had a similar experience with family and locals calling me tamasii muli, which translates to boy - foreigner or alien. This was my experience of growing up; the result of others positioning us in a displaced culture. I didn't care for these dislocated terms. But as kids, we thought it was normal, being called outsiders and not being part of this place and no matter what place we were at..$^{23}$
}

Through social events that are coordinated in cooperative ways, John's art practice engages with the experience of Pasifika edgewalkers as a state of limbo, understood as an experience of two or more cultures. Talanoa research methods privilege less rigid parameters, encouraging processes of storytelling in co-constructed layers. 


\section{Talanoa}

Timote Vaioleti argumenta que, historicamente, os métodos de investigação acadêmica foram conduzidos por hipóteses pré-formadas e questões de pesquisa. Argumenta sobre a importância de talanoa como uma metodologia de pesquisa orientada, entendida como "um encontro pessoal em que as pessoas relatam seus problemas, suas realidades e aspirações" (Vaioleti, 2006: 21 , grifo nosso). Talanoa é uma abordagem coletiva em sincronia com a forma como os povos do Pacífico operam, levando consigo protocolos éticos apropriados e talvez diferentes pressupostos ontológicos sobre a natureza da realidade (Vaioleti, 2006: 32). Vaioleti destaca os principais aspectos que são usados no processo talanoa como sendo encontros pessoais, de trocas e legitimidade de histórias. Ele também fala sobre talanoa como sendo a melhor maneira de coletar informações das comunidades do Pacífico. Esse método de comunicação face a face o torna mais pessoal com um grupo social típico (Vaioleti, 2006: 23). Enquanto Tala significa, entre outras coisas, informar, contar e relacionar, o sufixo Noa pode significar "ordinário, nada em particular, puramente imaginário ou vazio" (Vaioleti, 2006: 23). Vaioleti enfatiza uma espécie de queda livre de histórias e experiências relacionadas, afirmando que talanoa literalmente significa "falar sobre nada em particular e interagir sem um quadro rígido" (Vaioleti, 2006: 23). E com referência aos entendimentos samoanos de tala-

\section{Talanoa}

Timote Vaioleti argues that, historically, academic research methods have been driven by pre-formed hypotheses and research questions. He argues instead for the importance of talanoa as a driving research methodology understood as "a personal encounter where people story their issues, their realities and aspirations". ${ }^{24}$ Talanoa is a collective approach in sync with how Pacific peoples operate, carrying with it appropriate ethical protocols and perhaps different ontological assumptions about the nature of reality. ${ }^{25}$ Vaioleti highlights the key aspects that are used in the process of talanoa as being personal encounters, exchanging stories and the legitimacy of a story. He also talks about talanoa as being the best way for gathering information from the Pacific community. This method of face-to-face communicating makes it more personal with a typical social group. ${ }^{26}$ While Tala means, among other things, to inform, tell and relate, the suffix Noa can mean "ordinary, nothing in particular, purely imaginary or void". ${ }^{27}$ Vaioleti emphasises a kind of freefall of storytelling and related experiences, 
noa, Vaioleti refere-se a "discussões críticas em múltiplos níveis e multi-camadas e conversas livres" (Vaioleti, 2006: 24). Essas camadas de conversação fornecem potencial para "histórias co-construídas" (Vaioleti, 2006: 24).

\begin{abstract}
Me sinto chateado hoje porque tive uma experiência ruim nos estúdios. Estavamos conversando e eu disse algo sobre como eu estava questionando termos como "indígena" e "Pasifika" porque eles me lembram o termo "selvagem" e falam sobre selvagens. Então um amigo maori de um dos nossos candidatos maori me disse que não importava porque eu era apenas um imigrante. Ele usou a palavra imigrante. ${ }^{4}$
\end{abstract}

Vaioleti descreve talanoa como fenomenológica, em parte porque "elimina a distância entre pesquisador e participante e fornece aos participantes da pesquisa uma face humana à qual eles podem se relacionar" (Vaioleti, 2006: 25). Do nosso ponto de vista (John e Chris) isso se relaciona bem com o nosso campo de práticas de performance art, no qual a fenomenologia, com sua ênfase nas características de participação, tem sido uma voz dominante. Por exemplo, "Body Art / Performing the Subject (1998)", de Amelia Jones, marcou um momento crítico para uma reavaliação das maneiras pelas quais artistas, audiências e outros participantes poderiam ser compreendidos dentro de uma contingência de atuação (Jones, 1998: 9).

stating that talanoa literally means "talking about nothing in particular, and interacting without a rigid framework". ${ }^{28}$ And with reference to Samoan understandings of talanoa, Vaioleti refers to "multi-level and multi-layered critical discussions and free conversations". ${ }^{29}$ These layers of conversation provide potential for "co-constructed stories". ${ }^{30}$

I feel upset today because I've had a bad experience in the studios. A few of us were talking and I said something about how I was questioning terms like 'indigenous' and 'Pasifika' because they remind me of the term 'savage' and talking about savages. Then a Māori friend of one of our Māori candidates told me it didn't matter because I was just an immigrant. He used the word immigrant. ${ }^{31}$

Vaioleti describes talanoa as phenomenological partly because it "removes the distance between researcher and participant, and provides research participants with a human face they can relate to" ${ }^{32}$ From our 
Essa noção de contingência se desenvolve a partir de uma compreensão do corpo como fenomenologicamente "intersubjetivo" e tem ramificações profundas para pensar sobre corpos e eus na arte performática como co-construída e envolvida em interação recíproca (ver Braddock, 2013: 17-18). Estes são termos que Vaioleti usa em relação aos talanoa e estão também implícitos numa afirmação evocativa que os pesquisadores talanoa podem usar quando se apresentam a outro: "Ko 'eku ha'u keta talanoa ki ele... (eu vim para que possamos discutir / falar / conversar sobre...)" (Vaioleti, 2006: 26). Mas seria claramente uma oportunidade perdida e um descuido para contextualizar a dinâmica de talanoa dentro da trajetória dos estudos de desempenho euro-americanos, sem prestar atenção às suas genealogias ou epistemologias MNak únicas. Vaioleti está plenamente ciente dessa necessidade quando escreve: "É improvável que os pesquisadores cujo conhecimento é derivado de origens ocidentais tenham valores e realidades vividas que permitam a compreensão de questões relativas ao conhecimento e modos de ser originados dos nga wairua (espíritos) e whenua [terra] de Samoa, Tonga, Fiji, Tuvalu ou outras nações do Pacífico" (2006: 22). Nesta perspectiva, talanoa oferece protocolos de pesquisa do Pacífico, ou de ética, que guiam a maneira de John operar como artista performático envolvido em encontros sociais.

Esses protocolos de pesquisa incluem coisas como Faka 'apa' apa, que envolve comportamento respeitoso, humilde e atencioso, enquanto Anga Lelei diz respeito aos pesquisadores que entendem o contexto e a situação do participante de maneiras tolerantes, generosas, gentis, prestativas, calmas e dignas (Vaioleti, 2006). : 30). Existem muitos outros protocolos a serem considerados, mas um que se destaca para nós é 'ofa fe' unga que combina compaixão e generosidade a ponto de não haver mais nada para dar (Vaioleti, 2006: 31), enquanto tal generosidade é temperada em relação a uma dada situação. perspective (John and Chris) this relates well to our field of performance art practices where phenomenology, with its emphasis on characteristics of participation, has been a dominant voice. For example, Amelia Jones' 1998 Body Art/Performing the Subject marked a critical moment for a re-evaluation of the ways in which artists, audiences and other participants might be understood within a contingency of enactment. ${ }^{33}$ This notion of contingency develops from an understanding of the body as phenomenologically 'intersubjective' and has profound ramifications for thinking about bodies and selves in performance art as co-constructed and engaging in reciprocating interaction. ${ }^{34}$ These are terms that Vaioleti uses in relation to talanoa and they are also implicit in an evocative statement that talanoa researchers might use when introducing themselves to another: "Ko 'eku ha'u keta talanoa ki he... (I have come so that we can discuss/ talk about/converse about...)". ${ }^{35}$ But it would clearly be a missed opportunity and an oversight to contextualise the dynamics of talanoa within the Euro-American performance studies trajectory without paying attention to its unique MNak genealogies or epistemologies. Vaioleti is fully aware of this necessity when he writes: "Researchers whose knowing is derived from Western origins are unlikely to have values and lived realities that allow understanding of issues pertaining to knowledge and ways of being that originated from the nga wairua (spirits) and whenua (land) of Samoa, Tonga, Fiji, Tuvalu or the other Pacific nations" ${ }^{\prime \prime}$ From this perspective, talanoa offers Pacific research protocols, or ethics, that guide John's way of operating as a performance artist engaged with social encounters.

These research protocols include things like Faka 'apa 'apa which involves respectful, humble and considerate behaviour, while Anga Lelei concerns researchers understanding the participant's context and situation in ways that are tolerant, generous, kind, helpful, calm and dignified. ${ }^{37}$ There are many other protocols to be considered, but one that stands out for us is 'ofa fe' unga which combines compassion and generosity "to the point of there being nothing left to give away", ${ }^{38}$ while such generosity is tempered relative to a given situation. This ethical approach is also fundamentally about maintaining integrity and "not affecting the world of the participants in a negative or superficial way". ${ }^{39}$ 
Essa abordagem ética também se baseia fundamentalmente em manter a integridade e não afetar o mundo dos participantes de maneira negativa ou superficial (Vaioleti, 2006: 31).

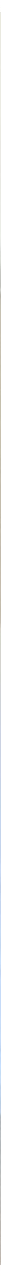

Fig 1. Emilia Maud Nixon Garden of Memories, Owairoa Marae (2016). Trocando talanoa com Kuia Taini Drummond e colaboradores, Valasi Leota-Seiuli's, Sione Mafi, Jimmy Wulf e Newman Tumata.
Fig 1. Emelia Maud Nixon Garden of Memories, Owairoa Marae (2016). Exchanging talanoa with Kuia Taini Drummond and collaborators, Valasi Leota-Seiuli's, Sione Mafi, Jimmy Wulf and Newman Tumata. 


\section{One Kiosk Many Exchanges}

One Kiosk Many Exchanges ocorreu no Jardim de Memórias Emilia Maud Nixon em Howick, Auckland, em 8 de outubro de 2016. O curador Bruce Phillips apresentou John a kuia (anciã) Taini Drummond, que é a kaitiaki (guardiã) deste jardim de Tainui desde 1984 que compreende um pequeno whare taonga (museu) chamado Te Raukohekohe com um wharenui (casa de reunião) chamado Owairoa Marae. Emilia Maude-Nixon (1870-1962), uma descendente de primeira geração de um britânico, organizou os jardins para fomentar relações próximas com as mulheres pioneiras pākeha e com o iwi local, Ngai Tai kī Tāmaki. Maude-Nixon era muito amada, e foi o amor dela pelo tangata whenua (povo da terra) que ativou sua visão. ${ }^{5}$

Taini Drummond passou o dia com todos os artistas, compartilhando as histórias deste lugar para que cada um deles pudesse fazer uma obra de arte informada e responsiva. Preocupado com questões de unidade, temporalidade, permanência, monumentalidade e espaço público, One Kiosk Many Exchanges teve como objetivo explorar como artistas contemporâneos locais de diferentes origens culturais poderiam cooperar por meio da arte da performance como um meio de navegar criticamente e inspirar o público ao discurso amigável. Após uma abordagem talanoa, o evento começou com uma palestra de Taini Drummond.

Eu fiz uma pergunta a kuia Drummond sobre a relação entre o povo do Pacífico e Tagua no Whenua. Acho que queria ter certeza de que estava fazendo algo de bom para ela. Ela respondeu comicamente: "somos todos iguais, vocês que saíram da waka mais cedo", aludindo à migração marítima do povo Moana Nui. ${ }^{6}$

\section{One Kiosk Many Exchanges}

One Kiosk Many Exchanges took place in the Emilia Maud Nixon Garden of Memories in Howick, Auckland, on 8 October 2016. Curator Bruce Phillips introduced John to kuia (female elder) Taini Drummond who is the kaitiaki (guardian) of this Tainui garden since 1984 which comprises a small whare taonga (museum) called Te Raukohekohe with a wharenui (meeting house) called Owairoa Marae. Emilia Maude-Nixon (1870-1962), a first-generation descendant of a British occupant, established the gardens to foster close relationships for pākehā pioneering women and the local iwi, Ngai Tai kī Tāmaki. Maude-Nixon was very much loved, and it was her love for tangata whenua (people of the land) that precipitated her vision. ${ }^{40}$

Taini Drummond spent the day with all the artists, sharing the stories of this place so that each of them could make an informed and responsive artwork. Concerned with issues of unity, temporality, permanence, monumentality and public space, One Kiosk Many Exchanges aimed to explore how local contemporary artists from different cultural backgrounds could cooperate through performance art as a means to critically navigate and inspire the public to friendly discourse. Following a talanoa approach, the event began with a talk by Taini Drummond.

\footnotetext{
I asked kuia Drummond a question about the relationship between the Pacific people and Tagnata Whenua. I guess, for me, I wanted to have assurance that I was doing something good on her behalf. She replied comically, "we are all the same, you guys just got off the waka earlier", alluding to the sea ferrying migration of the Moana Nui people. ${ }^{41}$
} 
A cooperação se desenrolou entre o coletivo H.E.P.T., um grupo de artistas conhecido apenas por sua sigla e cujas identidades não são especificadas em nenhuma forma escrita, e um grupo de estudantes de artes visuais da AUT University: Valasi Leota-Seiuli (Samoa), Newman Tumata ( Niuean), Jimmy Wulf (Samoan) e Sione Mafi (Tongan). Cada artista estudante foi convidado para formar uma troca com Owairoa Marae e o Jardim das Memórias, usando algum tipo de performance tradicional "atualizada".

Newman Tumata fez uma série de cartazes que empregavam imagens como sinais de gangues e gírias vernáculas dos vários subúrbios do sul de Auckland (a maior população polinésia do mundo). Como um vendedor de rua, ele deu a volta nos jardins e na rua tentando vender seus cartazes para dar koha (doação) a Owairoa em dólares da Nova Zelândia. Estas são as versões de taonga (tesouros) de Newman: palavras e objetos sinceros que emergem do espírito de South Auckland, onde Māori e MNak vivem, transpostos para as ruas Howick que ainda pertencem a Owairoa.

Sione Mafi honrou o whenua / fonua que pertence ao mana whenua Ngai Tai. Os vestígios invisíveis, mas sempre presentes, dos ancestrais de seu povo são sempre os primeiros a serem honrados na Māori tikanga (etiqueta / tradição). Sione preparou uma versão tradicional tonganesa da prática pan-pasifika da cerimônia de kava. Ao realizar o kava kuo heka se apresenta como

The cooperation unfolded between the H.E.P.T collective, a group of artists known only by their acronym and whose identities are not specified in any written form, and a group of visual art students from AUT University: Valasi Leota-Seiuli (Samoan), Newman Tumata (Niuean), Jimmy Wulf (Samoan) and Sione Mafi (Tongan). Each student artist was invited to form an exchange with Owairoa Marae and the Garden of Memories, using some form of 'updated' traditional performance.

Newman Tumata made a series of posters that employed imagery such as gang signs and vernacular slang from the various suburbs in South Auckland (the largest Polynesian population in the world). Like a street hawker, he went around the gardens and onto the street outside attempting to sell his posters in order to give koha (donation) to Owairoa in New Zealand dollars. These are Newman's version of taonga (treasures): heartfelt words and objects that emerge from the spirit of South Auckland where Māori and MNak live, transposed onto these Howick streets that still belong to Owairoa.

Sione Mafi honoured the whenua/ fonua/ which belongs to the mana whenua Ngai Tai. The invisible but ever-present traces of the ancestors of their people are always the first to be honoured in Māori tikanga (etiquette/ tradition). Sione prepared a traditional Tongan version of the pan-Pasifika practice of the kava ceremony. In performing the kava kuo heka he brings 
parente ancestral ao tangata whenua, mas ele também reconhece seu lugar de direito. Ele inclinou o primeiro gole de kava para a terra, que é a tradição, e depois passou a kava em volta dos participantes em um balde de plástico comum, diferente da casca de coco tradicional. Enquanto a kava é tradicionalmente servida apenas a dois homens, esse ritual contemporâneo envolvia todos os presentes, inclusive os invisíveis.

A troca de Valasi Leota-Seiuli com Owairoa foi uma performance ao vivo no local com palavras de ação. Ela cantou essas palavras como um encantamento para entrar no va (espaço) de dor e vergonha ex- himself as ancestral relative to tangata whenua but he also acknowledges their rightful place. He tipped the first sip of kava to the earth, which is the tradition, and then passed the kava around the participants in an everyday plastic bucket distinct from traditional coconut shell. Whereas kava is traditionally only served to men, this contemporary ritual involved everyone present, including those unseen.

Valasi Leota-Seiuli's exchange with Owairoa was an in-situ live performance of action words. She sung these words as an incantation to enter the va (space) of pain and shaming experienced by many migrant MNak, including her father, during the traumatic days of the Dawn Raids. ${ }^{42}$ In this va, these sung words connected her parents' woes with the

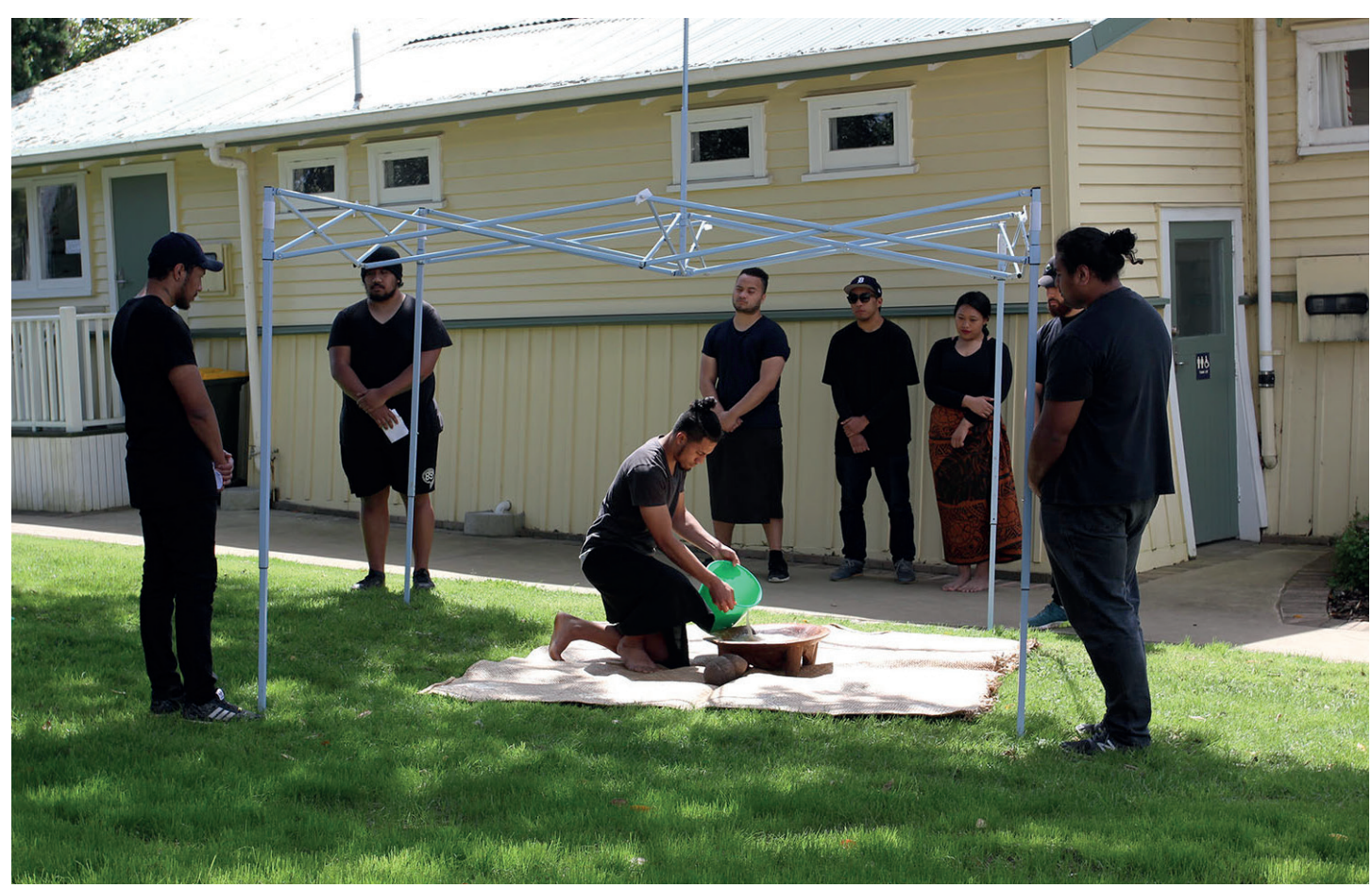

Fig 2. One Kiosk, Many Exchanges (2016) por John Vea.

Documentação da performance na Emilia Maud Nixon Garden of Memories, Howick. Foto cortesia de Te Tuhi Gallery.
Fig 2. One Kiosk, Many Exchanges (2016) by John Vea. Documentation of live performance at Emelia Maud Nixon Garden of Memories, Howick. Photo courtesy Te Tuhi Gallery. 
perimentado por muitos MNak migrantes, incluindo seu pai, durante os dias traumáticos dos Dawn Raids. Neste va, essas palavras cantadas conectaram os problemas de seus pais com o surpreendente e generoso legado de Emilia Maude-Nixon. The Dawn Raids permanece como uma das mais terríveis lembranças do perfil racial e da brutalidade do Estado na história do Aotearoa NZ para o MNak. As palavras de Valasi foram oferecidas como uma troca de histórias tristes com os tupuna (ancestrais) de Owairoa. Ela completou sua música com um ato de amor, colocando uma girlanda (importada da China de uma loja de US \$2) no memorial para Emilia Maude-Nixon.

\author{
Le Ula e, momoli atu e o'u lima \\ Le Ula e, momoli atu e o'u lima \\ E viia le folasia, lagi ma tuā lagi \\ Fatu e fusi ae le tumau \\ o tigā o'u tagata \\ Ua pese ai the failaga \\ Fa'afiafia, tama'ita'I sili \\ La'u asoa pale lona ao \\ Manatua agaalofa agalelei \\ Aso ua te'a, aso o tupulaga fou \\ Fico com essa lei na mão \\ Cantar para quem sulcou a terra \\ Eu recolho meu coração para trocar \\ Minhas palavras de canção de dor \\ de nossos povos \\ Eu canto para você, senhora, \\ meu colar é para você \\ Para honrar seu espírito \\ Do passado ao novo
}

Como Assistente de Graduação (GA) na Universidade de Tecnologia de Auckland (AUT), John se familiarizou com as práticas artísticas emergentes desses alunos. Conhecer as suas forças específicas permitiu-lhe encontrar formas de cooperar com a sua prática, que muitas vezes fomenta os resultados da "aldeia" ou da comunidade. Neste surprising and generous legacy of Emilia Maude-Nixon. The Dawn Raids remain as one of the single-most horrific memories of racial profiling and state brutality in the history of Aotearoa NZ for MNak. Valasi's words were offered as an exchange of sorrowful stories with the tupuna (ancestors) of Owairoa. She completed her song with an act of love, placing a lei (an imported Chinese one from a \$2 shop) on the memorial to Emilia Maude-Nixon.

Le Ula e, momoli atu e o'u lima
Le Ula e, momoli atu e o'u lima
E viia le folasia, lagi ma tuā lagi
Fatu e fusi ae le tumau
O tigā o'u tagata
Ua pese ai the failaga
Fa'afiafia, tama'ita'l sili
La'u asoa pale lona ao
Manatua agaalofa agalelei
Aso ua te'a, aso o tupulaga fou
I stand with this lei in hand
To sing to whom laid the land
I gather my heart to exchange
My words of song of our peoples' pain
I sing to you lady, my lei is for you
To honour your spirit
From the past to the new

As a Graduate Assistant (GA) at Auckland University of Technology (AUT), John has become familiar with these students' emerging art practices. Knowing their specific strengths enabled him to find ways they could cooperate with his practice which often fosters 'village' or community outcomes. In this event, the group employed objects and actions 'stolen' from other cultures such a kiosk or the practice of taking tea.

One Kiosk Many Exchanges was mindful of the way in which the suburb of Howick, formerly occupied by Ngāi Tai, was settled by Europeans in 1847 when three companies of the Royal New Zealand Fencibles were assigned to a defence post: "They were retired soldiers enlisted to serve for seven years in exchange for a cottage and an acre of land. Howick was the largest of the Fencible settlements, with 804 people in three 
evento, o grupo empregou objetos e ações "roubadas" de outras culturas, como um quiosque ou a prática de tomar chá.

One Kiosk Many Exchanges estava atento ao modo como o subúrbio de Howick, anteriormente ocupado por Ngāi Tai, foi colonizado por europeus em 1847, quando três empresas da Royal New Zealand Fencibles foram designadas para um posto de defesa: "Eram soldados aposentados. servir por sete anos em troca de uma casa de campo e um acre de terra. Howick foi o maior dos assentamentos de Fencible, com 804 pessoas em três empresas em 1848 "("This east Auckland suburb", 2018). A noção de roubo ou furto foi desenvolvida pela idéia do "quiosque" (um dossel portátil) que foi levado em uma procissão ao Jardim das Memórias pelo coletivo H.E.P.T, como um caixão é levado para um carro fúnebre.

Eu fiz algumas pesquisas na área e descobri sobre uma comunidade proeminente em Howick chamada de fencibles. Havia outras comunidades fencibles dentro de Auckland, mas nenhuma como a de Howick. Eles se orgulhavam da cultura e até têm uma Aldeia Histórica de Howick, dedicada ao envolvimento na ocupação de terras roubadas, aparentemente protegendo-as de invasores. Minha investigação da área de Howick foi muito profunda e acabei sendo convidado para jogar no clube local da liga de rugby, Howick Hornets. ${ }^{7}$

companies in $1848 " .43$ The notion of theft or taking-from another was fleshed out through the idea of the 'kiosk' (a portable canopy) which was carried in a procession to the Garden of Memories by the H.E.P.T collective, like a casket is carried to a hearse.

\footnotetext{
I did some research in the area and I found out about a prominent community in Howick called the fencibles. There were other fencible communities within Auckland but none like the one in Howick. They were proud of the culture and they even have a Howick Historical Village dedicated to the fencibles involvement in occupying stolen land apparently protecting it from attackers. My investigation of the Howick area was very in-depth and I ended up being roped into playing league for the local Rugby League club, Howick Hornets. ${ }^{44}$
} 
Os neozelandeses associam um quiosque (originário da Turquia / Pérsia) a uma barraca temporária no meio de um shopping center que vende produtos eletrônicos ou alimentos. Para o One Kiosk Many Exchanges, um quiosque foi carregado pelos "portadores" do H.E.P.T para cada um dos colaboradores do artista. Cada artista escolheu um local e performatizou com esse quiosque. Os portadores foram instruídos por seu "diretor" de forma muito silenciosa e sucinta, como se fosse algo que pudessem fazer regularmente:

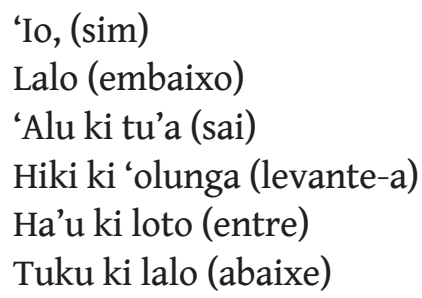

One Kiosk Many Exchanges foi co-optado por meio de uma trama de histórias co-construídas como ferramentas de pesquisa. John coleta histórias dentro de histórias, às vezes de conversas aleatórias com pessoas ao seu redor. Desta forma, os pesquisadores submergem em uma comunidade e, por meio desse processo talanoa, surgem evidências locais das comunidades específicas. A exposição de Jorge Satorre 2013 "Emic Etic?" no Artspace, Auckland, baseia-se nos termos "emic" e "etic"

New Zealanders associate a kiosk (originating from Turkey/ Persia) with a temporary stall in the middle of a shopping mall selling electronic goods or food. For One Kiosk Many Exchanges, a kiosk was carried around by the H.E.P.T 'bearers' for each of the artist collaborators. Each artist chose a location and performed within this one kiosk. The bearers were instructed by their 'director' very quietly and succinctly as if it was something they might do on a regular basis:

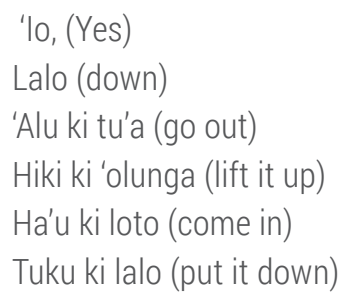

One Kiosk Many Exchanges was co-opted through a weave of co-constructed stories as a research tool. John collects stories-within-stories, sometimes from random conversations with people around him. In this way, researchers submerge themselves within a community and, through this process of talanoa, there emerges local evidence of the specific 
inventados pelo linguista norte-americano Kenneth Pike nos anos 1950. Os curadores Claudia Arozqueta e Caterina Riva afirmam que: "Uma abordagem de análise emica investiga o ponto de vista dos nativos ou locais em um contexto específico. A abordagem etic incorpora a opinião de um pesquisador ou pesquisador baseado em versões locais ou discursos "(Arozqueta \& Riva, 2013, n.p). A obra de arte do Satorre explora esses pontos de vista enquanto ele pesquisa o significado cultural das aves nativas e do jade a partir da perspectiva de um visitante em Aotearoa NZ (Arozqueta \& Riva, 2013, n.p)

Eu fiz amizade com kuia Drummond que gentilmente compartilhou comigo a história do Jardim das Memórias através de talanoa. Ela era como uma conselheira cultural / comunitária que me orientou sobre como negociar o espaço do meu ponto de vista ético. Ela se tornou meu portal emico para a comunidade de Howick. Como eu estava pesquisando apenas a partir de uma perspectiva ética, ela me ajudou de dentro da cultura. ${ }^{8}$

As características da pesquisa êmica são intensificadas pela ênfase talanoa em ouvir as histórias das pessoas, não importa onde elas possam levar e pela profunda preocupação com o conhecimento proveniente de wairua e whenua. Voltando às complexidades dos pesquisadores como edgewalkers Pasifika, Tupuola afirma:

Minha origem étnica e cultural também desempenhou um papel vital em ser capaz de tecer meus papéis como pesquisador interno e externo. Meu próprio status como parte de um grupo minoritário na Nova Zelândia gerou o interesse de jovens afro-americanos, hispânicos, chicanos e latinos e os encorajou a compartilhar suas experiências comigo. Além disso, durante o curso deste estudo, foi interessante ver communities. Jorge Satorre's 2013 exhibition Emic Etic? at Artspace, Auckland, draws on the terms 'emic' and 'etic' coined by American linguist Kenneth Pike in the 1950s. Curators Claudia Arozqueta and Caterina Riva state that: "An Emic analysis approach investigates the point of view of the natives or locals in a specific context. The Etic approach incorporates the opinion of an investigator or researcher based on local versions or discourses" ${ }^{45}$ The artwork of Satorre explores these viewpoints as he researches the cultural significance of native birds and greenstone from a visitor's perspective in Aotearoa NZ. ${ }^{46}$

\begin{abstract}
I befriended kuia Drummond who kindly shared with me the history of the Garden of Memories through talanoa. She was like a cultural/community advisor who mentored me in how to negotiate the space from my etic stand point. She became my emic gateway to the community of Howick. As I was only researching from an etic perspective she assisted me from inside the culture. ${ }^{47}$
\end{abstract}

The characteristics of emic research are heightened by talanoa's emphasis on listening to peoples' stories no matter where they may lead and by deep concern for knowledge originating from wairua and whenua. Returning to the complexities of the researchers as Pasifika edgewalkers, Tupuola states:

\footnotetext{
My ethnic and cultural background also played a vital role in being able to weave between my roles as both insider and outsider researcher. My own status as part of a minority group in New Zealand engendered interest from African-American, Hispanic, Chicano and Latino youth and encouraged them to share their experiences with me. Furthermore, during the course of this study, it was interesting to see how similar some of the cultural practices were, despite my being of a different background. Thus, in designing the research method, I thought it best that this research be divided into three phases: the first being a theoretical critique and analysis of the achieved identity status; the second, fieldwork and third, a video documentary. The different phases of the study were collaborated upon with youth, in particular the selection of films, poetry, texts, graffiti, lyrics and theatre. ${ }^{48}$
} 
como algumas práticas culturais eram similares, apesar de eu ter uma formação diferente. Assim, ao projetar o método de pesquisa, julguei melhor que fosse dividida em três fases: a primeira sendo uma crítica teórica e uma análise do status identitário alcançado; o segundo, trabalho de campo e terceiro, um documentário em vídeo. As diferentes fases do estudo foram colaborativas com os jovens, em particular a seleção de filmes, poesia, textos, graffiti, letras e teatro. (Tupuola, 2004: n.e.)

Em resumo, uma abordagem êmica olha para uma cultura de dentro, enquanto uma abordagem ética olha para uma cultura de fora. A diferença marcante entre Jorge Satorre e John Vea é que Satorre incorpora o etnógrafo e Vea, o auto-etnógrafo: Satorre luta com os problemas associados a modos arbitrários de interpretação de outra cultura, enquanto Vea explora sua própria cultura MNak e os tipos de escolhas de pesquisas baseadas em práticas, nas quais visa as abordagens de pesquisas hegemônicas do passado e, não menos, aquelas que enquadraram o MNak como menos do que racionais.

\section{Limbo}

Essas histórias evocam um estado de limbo, tamasi'i muli (estrangeiro ou gringo) em sua própria terra, devido aos legados do colonialismo, imperialismo, capitalismo e racionalismo econômico. O termo limbo originou-se da palavra latina limbus, que significa borda ou região na fronteira do Inferno. A crença cristã medieval dizia que somente aqueles que foram batizados na Igreja Cristã poderiam entrar no céu, e o limbo era a morada das almas de crianças não batizadas, e dos justos que morreram antes da vinda de Cristo: na fronteira; não no inferno, mas também não no céu. Sinônimos de esquecimento, vazio e a inexistência, o limbo tornou-se uma metáfora e / ou estado físico de não pertencer a um lugar ou estar entre espaços.
In summary, an emic approach looks into a culture from the inside while an etic approach looks into a culture from the outside. The striking difference between Jorge Satorre and John Vea is that Satorre embodies the ethnographer and Vea the auto-ethnographer: Satorre struggles with the problems associated with arbitrary modes of interpretation of another culture while Vea explores his own MNak culture and the kinds of practice-based research decisions he can make that address hegemonic research approaches of the past and not least those that have framed MNak as less than rational.

\section{Limbo}

These stories evoke a state of limbo, even tamasi'i muli (foreigner or alien) in one's own land due to the legacies of colonialism, imperialism, capitalism and economic rationalism. The term limbo originated from the Latin word limbus meaning edge or region on the border of Hell. Medieval Christian belief had it that only those who were baptized into the Christian Church could enter heaven, and limbo was the abode of the souls of unbaptized infants, and of the just who died before Christ's coming: on the border; not in hell, but not in heaven either. Synonyms with oblivion, void and non-existence, limbo has become a metaphor and/or physical state of not belonging to a place or being in between spaces. 
Como sou samoano-alemão criado em Samoa na Nova Zelândia, nunca encontrei minha família alemã, encontrei uma foto antiga do meu bisavô. Eu aprendi algumas frases em alemão da internet para tentar me comunicar com meu avô através da imagem. ${ }^{9}$

O ponto de vista mítico de talanoa, reunindo informações do interior de uma sociedade, vem com um entendimento tácito de que este é um processo falho, que desenvolve subjetividades dentro de um estado cultural de limbo. Uma história vem à luz dentro de uma história coletada e a ideia de uma história dentro de uma história é comum à pesquisa de John. O que se segue é um relato de 'Aloha' Aina Fonua no Havaí, onde as pressões de tempo de uma residência de pesquisa em Honolulu testaram métodos de pesquisa de talanoa:

Tornei-me muito consciente de mim mesmo como estranho olhando para dentro da cultura. Até esta residência, eu só tenho reunido talanoa em Aotearoa onde moro. Ser o estranho era mais uma experiência estrangeira; embora parecesse um local, assegurei-me de que os habitantes locais havaianos soubessem de onde eu vinha. Eu particularmente não queria responder à minha residência de pesquisa para criticar a área que eu pesquisei, mas sim me criticar usando as noções coletadas do Havaí. ${ }^{10}$

Because I'm Samoan German raised fa'a samoa (samoan way) in NZ, I've never met my German family, I found an old photo of my great Grandfather. I learnt some German phrases from the internet to try and communicate with my Grandfather through the image. ${ }^{49}$

Talanoa's emic viewpoint, gathering information from the inside of a society, comes with a tacit understanding that this is a flawed process, which develops subjectivities within a cultural state of limbo. A story comes to light within a story being gathered and the idea of a story-within-a-story is common to John's research. What follows is an account of 'Aloha 'Aina Fonua in Hawaii where the time pressures of a research residency in Honolulu tested talanoa research methods:

I became very conscious about myself as the outsider looking inside the culture. Until this residency, I have only been gathering talanoa within Aotearoa where I live. Being the outsider was yet another foreign experience; even though I looked like a local I made sure the Hawaiian locals knew where I came from. I particularly did not want to respond to my research residency to critique the area I researched but rather critique myself using the notions gathered from Hawaii. ${ }^{50}$ 
Tomando um ônibus da Universidade do Havaí, perguntei a um local sentado ao meu lado em busca de instruções para ir a Chinatown, em Honolulu, Havaí. Ele me mostrou as direções em um mapa em seu telefone. Nós continuamos tendo um talanoa em coisas gerais acontecendo no Havaí. Ele apontou para um subúrbio montanhoso, "você sabe lá, você precisa de $50 \%$ de sangue havaiano para viver lá." Meu ponto de ônibus estava chegando, e eu não entendi o que ele queria dizer, então eu apenas balancei a cabeça como se eu entendi e saí do ônibus. Mais tarde eu pesquisei o percentual de sangue havaiano, e o primeiro site que aparece é: Candidatando-se a terras havaianas - Departamento de Casa Havaiana. Para poder viver nessas propriedades havaianas, você precisa ter uma certa porcentagem de sangue havaiano. ${ }^{12}$

Ngahiraka Mason, diretora curatorial da Bienal de Honolulu de 2017, levou John a uma fazenda orgânica chamada Ma'o, localizada na área de Waianae, no Havaí Oahu. Ngahiraka o apresentou a Cheryse Sana e Kamuela Enos, que são co-gestoras da fazenda. Eles mostraram John ao redor da plantação e conversaram sobre como eles trabalham principalmente com crianças que acabaram de sair do ensino médio e se dirigiram para a faculdade. Uma organização sem fins lucrativos, as fazendas Ma'o exploram os desafios da juventude e da comunidade por meio da agricultura havaiana tradicional.

\footnotetext{
Caughting a bus from the University of Hawaii, I asked a local sitting next to me for directions to get to go to Chinatown in Honolulu Hawaii. He showed me directions on a map on his phone. We continued having a talanoa on general stuff happening in Hawaii. He pointed to a hilly suburb, "you know over there, you need 50\% Hawaiian blood to live there." My bus stop was coming up, and I didn't get what he meant, so I just nodded my head as if I understood and got off the bus. Later I googled Hawaiian blood percentage, and the first website that shows up is: Applying for Hawaiian Home Lands - Department of Hawaiian Home. To be able to live in these Hawaiian homesteads you have to have a certain percentage of Hawaiian blood..$^{52}$
}

Ngahiraka Mason, curatorial director of the 2017 Honolulu Biennial, took John to an Organic farm called Ma'o farms based in the Waianae area in Hawaii Oahu. Ngahiraka introduced him to Cheryse Sana and Kamuela Enos who are co-managing the farm. They showed John around the plantation and talked about how they mainly work with kids who have just left high school and heading for college. A non-profit organisation, Ma'o farms explores challenges for youth and community through traditional Hawaiian agriculture. 
Na fazenda, passamos por uma grande pilha de rochas retiradas da terra. $\mathrm{O}$ modo como as rochas eram organizadas parecia a formação de rochas que cercam uma casa em Tonga. A pilha de pedras provocou em mim uma história sobre a situação da minha mãe possuir terras em Tonga. ${ }^{13}$

'Aloha' Aina Fonua responde ao conceito havaiano nativo de Aloha Âina (amor à terra) dentro do contexto da terra natal de John. Em Tonga, as mulheres são incapazes de possuir fonua (terra) em contraste com os valores e direitos da terra havaiana.

Minha mãe é a mais velha das três irmãs do sexo feminino. Para contornar essas leis, minha mãe assinou a fonua do meu avô com meu nome, pois eu sou o neto masculino mais velho. Recentemente, um parente distante do lado do meu avô da família tentou reivindicar esta fonua, que causou uma batalha legal sob a lei tonganesa entre famílias. Ficamos no limbo à espera de uma decisão ou resolução. A obra de arte é baseada em um jogo da minha infância chamado Eggs in a Basket, que envolve roubar o máximo de pedras possíveis dos oponentes dentro do prazo alocado. Aplico esse conceito de competir por propriedade no contexto mais sinistro da batalha de minha mãe para manter sua casa. Ela semeia esta āina com seus irmãos mais novos, mas ela não pode herdar a mesma āina. ${ }^{14}$

In the farm, we walked past a large pile of rocks retrieved from the land. The way the rocks were organised looked like the formation of rocks that surround a house in Tonga. The pile of rocks triggered a story in me about my mother's situation owning land in Tonga ${ }^{53}$

'Aloha 'Aina Fonua responds to the Native Hawaiian concept of Aloha Äina (love of the land) within the context of John's Tongan homeland. In Tonga, women are unable to own fonua (land) in contrast with Hawaiian land values and rights.

\footnotetext{
My mother is the eldest out of three female siblings. To bypass these laws my mother signed my Grandfather's fonua under my name, as I am the eldest male grandchild. Recently a distant male relative from my Grandfather's side of the family has tried to lay claim to this fonua, which has caused a legal battle under Tongan law between families. We are left in limbo awaiting a decision or resolution. The artwork is based on a game from my childhood called Eggs in a Basket which involves stealing as many rocks as possible from opponents within the allocated time frame. I apply this concept of competing for ownership within the more sinister context of my mother's battle to retain her home. She sows this āina with her younger siblings, yet she cannot inherit that same āina. ${ }^{54}$
} 


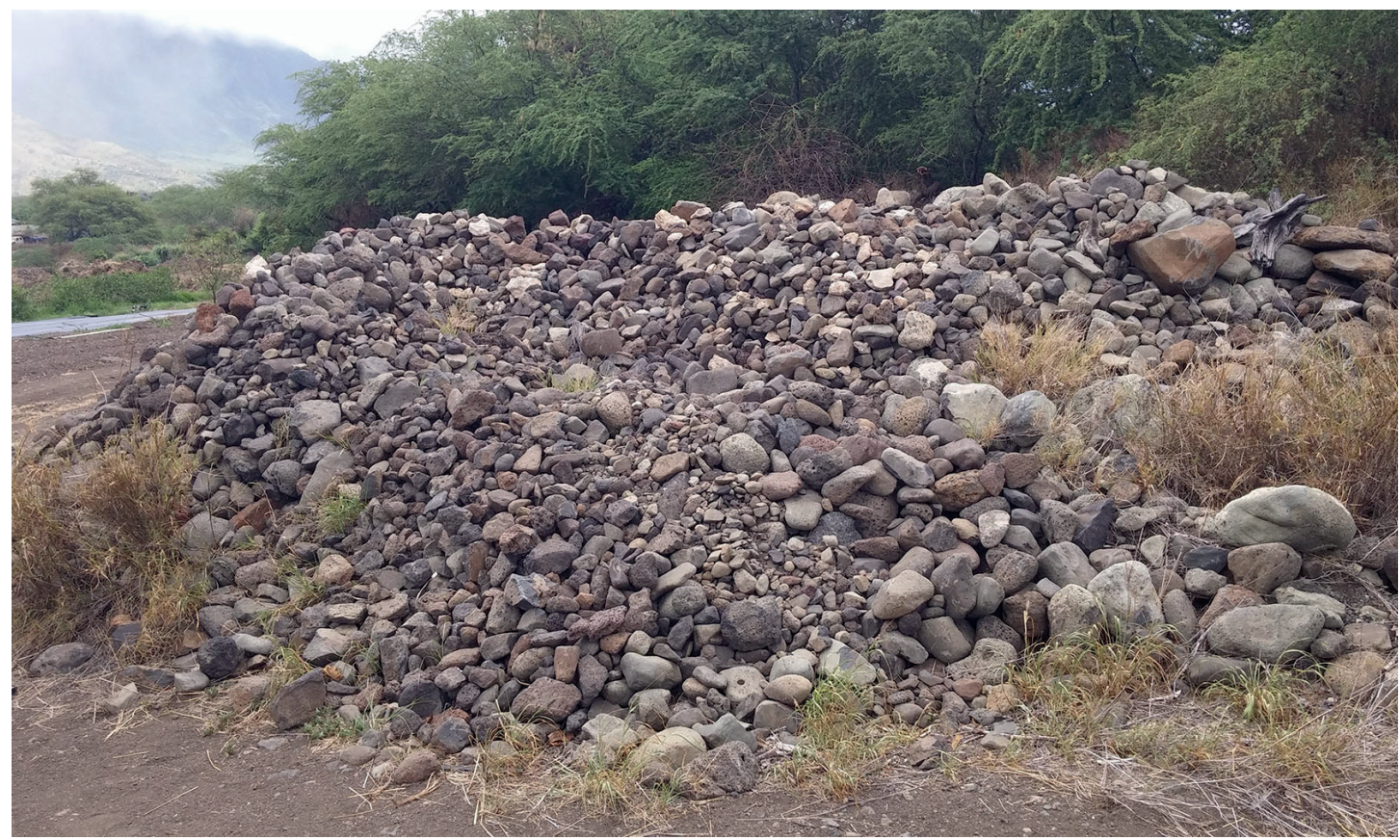

Fig 4. Pile of Rocks (2016). Ma'o Farms, Waianae, Oahu, Hawaii.

Fig 4. Pile of Rocks (2016). Ma'o Farms, Waianae, Oahu, Hawaii.

A próxima seção explora as idéias de ativismo artístico de Chantel Mouffe e espaços agonísticos de cooperação compartilhadas que estão em um terreno comum com a idéia de pesquisadores como edgewalkers de Pasifika. Um estado de limbo (não pertencente a lugar ou estar entre espaços), parece alinhar com a insistência de Mouffe para práticas políticas que criam "espaços públicos agonísticos" que evitam todas as formas de consenso (Mouffe, 2007: 4). Mas como nos engajamos em formas de políticas democráticas antagônicas (Mouffe, 2007, p. 3, 5), comprometidas com talanoa?
The next section explores Chantel Mouffe's ideas of artistic activism and agonistic spaces of shared cooperation that shares common ground with the idea of researchers as Pasifika edgewalkers. A state of limbo (not belonging to place or being in between spaces), seems to align with Mouffe's insistence for political practices that create "agonistic public spaces" that avoid all forms of consensus. ${ }^{55}$ But how do we engage in forms of adversarial democratic politics ${ }^{56}$ while being committed to talanoa? 


\section{Antagonismo de Chantel Mouffe}

O ensaio de Chantel Mouffe, 'Artistic Activism and Agonistic Spaces' defende a importância de práticas artísticas críticas em espaços públicos que nunca buscam consenso. Ela procura uma arte que reconheça diferenças políticas antagonistas radicais insustentáveis e insolúveis.

o que quer dizer Mouffe quando descreve o político como antagonismo? Ela quer dizer que "questões políticas sempre envolvem decisões que nos obrigam a escolher entre alternativas conflitantes" (Mouffe, 2007: 2). Isto sugere que as sociedades e os políticos são locais de pluralidade e conflito nos quais as soluções racionais nem sempre são evidentes (Mouffe, 2007: 2). Assim, o antagonismo é uma dimensão inevitável e necessária do político. Mouffe argumenta que o neoliberalismo é, por nature$\mathrm{za}$, racionalista e individualista em sua abordagem e "incapaz de compreender adequadamente a natureza pluralista do mundo social" (Mouffe, 2007: 2). Uma das principais razões, segundo Mouffe, para a incapacidade do neoliberalismo de compreender e se relacionar com diferenças complexas na sociedade é a sua "crença racionalista na disponibilidade de um consenso universal baseado na razão" (Mouffe, 2007: 2). Em contraste, ela escreve que "o antagonismo revela o próprio limite de qualquer consenso racional" (Mouffe, 2007: 2). A partir dessa perspectiva, Mouffe argumenta que a democracia é paradoxal, envolvendo

\section{Chantel Mouffe's Antagonism}

Chantel Mouffe's essay 'Artistic Activism and Agonistic Spaces' argues for the importance of critical artistic practices in public spaces that never seek consensus. She seeks out art that acknowledges radical antagonistic political differences that are unsustainable and unresolvable.

What does Mouffe mean when she describes the political as antagonism? She means that "political questions always involve decisions which require us to make a choice between conflicting alternatives" ${ }^{\prime 7}$ This suggests that societies and the political are sites of plurality and conflict where rational solutions are not always evident..$^{58}$ Thus, antagonism is an unavoidable and necessary dimension of the political. Mouffe argues that neo-liberalism is by nature rationalist and individualist in its approach and "unable to grasp adequately the pluralistic nature of the social world". ${ }^{59}$ One of the main reasons, according to Mouffe, for neo-liberalism's inability to grasp and relate to complex differences in society is its "rationalist belief in the availability of a universal consensus based on reason". ${ }^{60}$ By contrast, she writes that "antagonism reveals the very limit of any rational consensus". ${ }^{61}$ From this perspective, Mouffe argues that democracy is paradoxical, involving an "agonistic struggle.... between opposing hegemonic 
uma "luta agonística". entre projetos hegemônicos opostos que nunca podem ser reconciliados racionalmente "(Mouffe, 2007: 3). Isto implica que, para o sucesso da democracia, ela deve reconhecer as sociedades como precárias e instáveis; sociedades que defendem o que ela chama de política democrática antagônica. E isso também significa lembrar continuamente práticas históricas hegemônicas anteriores, ou seja, a história e as práticas sociais atuais nunca são neutras.

O que pode ser radical sobre a luta agonística de Mouffe é sua resistência a idéias de acordo intersubjetivo e consenso (e aqui ela contrasta seu trabalho com o de Jürgen Habermas e Hannah Arendt). Ao abordar exclusões e diferenças radicais sem buscar formas racionais de consenso, as hegemonias dominantes são questionadas (Mouffe, 2007: 4). O que é importante para nossa discussão aqui sobre o espaço público e o papel criticamente político das práticas artísticas é que, primeiramente, “o espaço público é o campo de batalha onde diferentes projetos hegemônicos são confrontados, sem qualquer possibilidade de reconciliação final" (Mouffe, 2007: 3). e, segundo, a política e a arte nunca podem ser separadas: "existe uma dimensão estética no político e existe uma dimensão política na arte" (Mouffe, 2007: 4).

Práticas artísticas críticas que criam "espaços públicos agonísticos" vão "desvelar tudo o que é reprimido pelo consenso dominante" e, portanto, evitará todas as formas de consen-

projects which can never be reconciled rationally". ${ }^{62}$ This implies that for democracy to succeed it must recognise societies as precarious and unstable; societies that advocate what she calls adversarial democratic politics. And this also means continually remembering previous historic hegemonic practices i.e., history and current social practices are never neutral.

What might be radical about Mouffe's agonistic struggle is her resistance to ideas of intersubjective agreement and consensus (and here she contrasts her work with that of Jürgen Habermas and Hannah Arendt). Dominant hegemonies are questioned by pursuing radical exclusions and differences without seeking rational forms of consensus. ${ }^{63}$ What is important for our discussion here about both public space and the critically political role of artistic practices is that, firstly, "public space is the battleground where different hegemonic projects are confronted, without any possibility of final reconciliation" 64 and, secondly, politics and art can never be separated: "There is an aesthetic dimension in the political and there is a political dimension in art". 65

Critical artistic practices that create "agonistic public spaces" are going to "unveil all that is repressed by the dominant consensus" and will therefore avoid all forms of consensus. Mouffe's definition of agonistic art is therefore "art that foments dissensus, that makes visible what the 
so. A definição de arte agonística de Mouffe é, portanto, “arte que fomenta o dissenso, que torna visível o que o consenso dominante tende a obscurecer e a obliterar" (Mouffe, 2007: 4). Ela dá exemplos do que ela chama de "práticas artístico-ativistas" como " "Reclaim the streets" na Grã-Bretanha ou 'Tute Bianche' na Itália, para as campanhas ‘Stop advertising' na França e 'Nike Ground-Rethinking Space' em Áustria "(Mouffe, 2007: 5).

Significativamente, Mouffe se opõe a algumas concepções modernistas do artista como privilegiados e únicos, fazendo algum tipo de crítica social de vanguarda. A esse respeito, os artistas agonistas não podem ser vistos como interventores de qualquer situação política, mas sim artistas, como todos os outros, são inseparáveis e contingentes aos mesmos problemas que "criticam". Somente quando essas ilusões modernistas artísticas são abandonadas é que a arte pode tornar-se produtivamente parte de uma política democrática antagônica (Mouffe, 2007: 3, 5).

A maioria das histórias que John reúne comentam questões pós-coloniais que afetam as pessoas com as quais ele conversa, como trabalhadores de fábrica, faxineiros, trabalhadores sazonais, motoristas de táxi, líderes religiosos, refugiados e assim por diante. A maioria dos participantes dos projetos de John são migrantes para a Aotearoa NZ ou filhos de imigrantes. As histórias revelam que o edgewalker de Pasifika negocia constantemente a hegemonia cultural. Mas a natureza do edgewalk

dominant consensus tends to obscure and obliterate". ${ }^{66}$ She gives examples of what she calls "artistico-activist practices" such as "Reclaim the streets' in Britain or the 'Tute Bianche' in Italy to the 'Stop advertizing' campaigns in France and the 'Nike Ground-Rethinking Space' in Austria". ${ }^{67}$

Significantly, Mouffe is opposed to some modernist conceptions of the artist as privileged and unique, making some kind of avant-garde social critique. In this respect, agonistic artists cannot be seen as intervening in any political state of affairs but rather, artists, like everyone else, are inseparable from, and contingent in, the very problems they 'critique'. It is only when these artistic modernist illusions are abandoned that art might productively become part of an adversarial democratic politics. ${ }^{68}$

The majority of stories that John gathers comment on post-colonial issues that affect the people he converses with such as factory workers, cleaners, seasonal workers, taxi drivers, religious leaders, refugees and so on. Most of the participants in John's projects are migrants to Aotearoa NZ or offspring of immigrants. The stories reveal that the Pasifika edgewalker constantly negotiates cultural hegemony. But the nature of the edgewalker equally permeates the critical methodologies in John's research practice. For example, how do we control quality in these cooperative social artworks without dominating them with instructions or a curatorial overview? How 
igualmente permeia as metodologias críticas na prática de pesquisa de John. Por exemplo, como podemos controlar a qualidade dessas obras de arte sociais cooperativas sem dominá-las com instruções ou uma visão curatorial? Como articular um fluxo de histórias dentro de histórias torna-se um "problema" construtivo para o pesquisador talanoa. Discutido na próxima seção, “Mo'ui Tukuhausia incorpora esses desafios em todo o espaço público e uma sensação extensa de tempo de vida.

\section{‘Mo'ui Tukuhausia}

O ponto de vista emico é evidente em Mo'ui Tukuhausia, 2012, pelo artista tonganês / neozelandês Kalisolaite" Uhila, parte da exposição do grupo "O que você quer dizer, nós?" na galeria de arte Te Tuhi em Pakuranga, Auckland. Para este trabalho, Uhila viveu como sem-teto nos prédios de Te Tuhi e nas áreas ao redor durante duas semanas. Esta obra contribuiu para o Prêmio Walters na Galeria de Arte de Auckland em 2014, quando viveu nas ruas por três meses. Ele cruzou caminhos com uma pessoa sem-teto local durante sua empreitada. Depois de explicar aos sem-teto que sua experiência de viver sem-teto como uma obra de arte, essa pessoa respondeu: "Mano, estou feliz que você esteja fazendo isso, cara, é bom que alguém esteja fazendo isso para nos entender melhor". De certa forma, o sem-teto reconhece como o ponto de vista êmico é importante para entender uma cultura, uma preocupação central para o 'Mo'ui Tukuhausia e seus processos. $O$ curador Bruce Phillips explica: to articulate a flow of stories within stories becomes a constructive 'problem' for the talanoa researcher. Discussed in the next section, 'Mo'ui Tukuhausia embodies these challenges across public space and an extended sense of lived time.

\section{'Mo'ui Tukuhausia}

The emic viewpoint is evident in 'Mo'ui Tukuhausia, 2012, by Tongan/New Zealand artist Kalisolaite 'Uhila, part of the group exhibition What do you mean, we? at Te Tuhi art gallery in Pakuranga, Auckland. ${ }^{69}$ For this artwork 'Uhila lived homelessly around Te Tuhi's buildings and the surrounding areas for the duration of two weeks. This artwork developed into 'Uhila's contribution for The Walters Prize at the Auckland Art Gallery in 2014 when he lived on the streets for three months. He crossed paths with a local homeless person during his endeavor. After explaining to the homeless person that his experiment of living homeless as an artwork, that person replied: "Bro, I am glad you are doing that, man, it is good that someone is doing this to understand us better". In a way, the homeless person recognises how the emic viewpoint is important for understanding a culture, a central concern for 'Mo'ui Tukuhausia and its processes. Curator Bruce Phillips explains: 


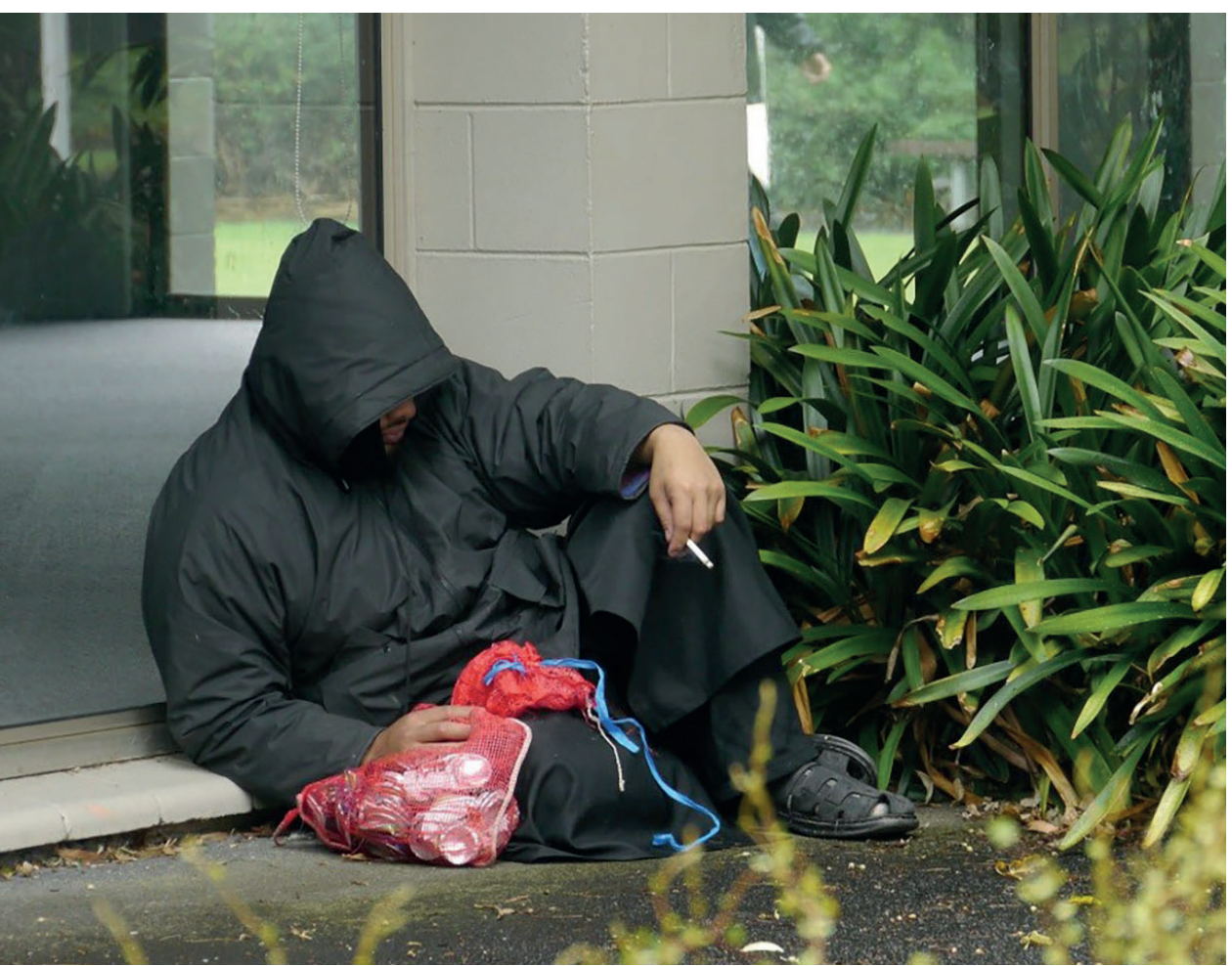

Fig 5. Mo'ui Tukuhasia (2012) por Kalisolaite 'Uhila. Documentação de performance na Te Tuhi Gallery. Foto cortesia de Te Tuhi Gallery.

Fig 5. Mo'ui Tukuhasia (2012) by Kalisolaite 'Uhila. Documentation of live performance at Te Tuhi Gallery. Photo courtesy Te Tuhi Gallery.

Kalisolaite era visitado periodicamente por amigos, familiares e simpatizantes, mas na maioria das vezes era deixado sozinho para existir dia e noite a céu aberto, como muitas outras pessoas fazem nos centros urbanos ao redor do mundo. A necessidade de aprender a sobrevivência urbana, para mim, está entre as mais perspicazes de suas narrativas. Ele me disse: "Um aspecto fundamental para a sobrevivência é estar ciente do seu entorno ... Eu estava fazendo muitas coisas sentadas, muita observação, apenas ouvindo e percebendo o que estava acontecendo na área. Foi quando percebi que realmente não precisava saber a hora, porque essa era a minha hora. Ao prestar atenção ao que estava acontecendo ao redor da área, eu notaria a vida acontecendo como um relógio ... mas é mais como uma sombra do tempo. As pessoas tinham tempo, mas eu estava me movendo na sombra delas. Eles estariam se movendo, mas eu estava me movendo no meu ritmo diferente ". (Phillips, 2014, n.p.)

Kalisolaite was periodically visited by friends, family and supporters but was on the most part left alone to exist day and night in the open like many other people do in urban centres around the globe. The necessity of learning urban survival is amongst the most insightful of his accounts to me. He told me: "A key aspect to survival is to be aware of your surroundings ... I was doing a lot of sitting, a lot of observing, just listening and being aware of what was happening around the area. That was when I realised that I didn't really need to know the time, because this was my time. By paying attention to what was going on around the area I would notice life happening like clockwork ... but it is more like a shadow of time. People had the time but I was moving in their shadow. They would be moving but I was moving at my own different pace" ${ }^{70}$ 


\section{Conclusão}

Começamos a procurar um terreno comum e diferenças entre as ideias de Vaioleti e Mouffe. One Kiosk Many Exchanges explora o papel do artista pesquisador que procura cooperar com coletivos e pequenos grupos e, portanto, desbancar a ideia do pesquisador privilegiado como conhecedor de uma crítica decisiva à sociedade. Assim como com a definição de arte agonística de Mouffe, a prática da performance de John Vea está enredada e dependente do tecido das histórias e dos problemas que eles criticam. O estado de limbo de sua família em 'Aloha' Aina Fonua, ao furtarem freneticamente as rochas uns dos outros em um jogo de Eggs in a Basket, deixa suas mulheres afastadas dos direitos de propriedade da terra; não pertencendo ao seu lugar e constantemente existindo entre espaços. Como Kalisolaite 'Uhila está abandonando o tempo do relógio enquanto vive nas ruas como um sem-teto, essas existências limbo (incorporadas em encenações de desempenho profundas) trazem a arte na política democrática contraditória desejada por Mouffe (Mouffe, 2007: 3, 5). Eles também se alinham com as idéias de Vaioleti sobre a metodologia de pesquisa talanoa com suas histórias abertas e formas altamente contingentes de início e fim (uma história em um ônibus ou uma visita da polícia) que minam a confiabilidade e consistência nos resultados de pesquisas acadêmicas tradicionais.

\section{Conclusion}

We began searching out common ground and differences between the ideas of Vaioleti and Mouffe. One Kiosk Many Exchanges explores the role of the artist researcher who seeks out co-operations with collectives and small groups and therefore debunking the idea of the privileged researcher as connoisseur of decisive critique on society. As with Mouffe's definition of agonistic art, John Vea's performance practice is enmeshed and contingent with the fabric of stories and the problems they critique. His family's state of limbo in 'Aloha 'Aina Fonua, as they frantically steal rocks from each other in a game of Eggs in a Basket, leaves their women estranged from the rights of landownership; not belonging to their place and constantly existing between spaces. Like Kalisolaite 'Uhila's relinquishing of clock time while living on the streets as a homeless person, these limbo existences (embodied in absolutely profound performance enactments) bring art into Mouffe's desired adversarial democratic politics. ${ }^{71}$ They also align with Vaioleti's ideas about talanoa research methodology with their open-ended stories and highly contingent ways of beginning and ending (a story on a bus or a visit from the police) that undermine reliability and consistency in traditional academic research results. 
Talanoa de John nos ensina algo sobre o estado de limbo que caminha cautelosamente entre ofa fe 'unga (compaixão e generosidade) a ponto de não haver mais nada para dar "(Vaioleti, 2006: 31) e uma política adversarial no qual o espaço público é um campo de batalha dos diferentes poderes sociais. Esses campos de batalha abordam uma miríade de histórias e histórias hegemônicas envolvendo Māori e pākehā, povos Maori e Moana Nui, Moana Nui e pākehā, a constituição do Reino de Tonga e, não menos importante, o direito de cada pessoa de possuir um lugar seguro e acolhedor para viver. 0 tipo de talanoa defendido nessas obras de arte sociais e cooperativas pode encontrar momentos de profunda reconciliação com indivíduos e coletivos, como a conversa de Uhila com 'outro' sem-teto e a conversa fugaz de John em um ônibus local no Havaí sobre a posse da terra. Somos sérios sobre desafiar a academia em formas de pesquisa que se originam dos nga wairua (espíritos) e whenua (terra) de todos os povos. Este é um antagonismo que tenta combinar ofa fe unga com uma dimensão política que afronta o racismo, o patriarcado e o neoliberalismo na sua incapacidade de compreender a natureza pluralista do mundo social (ver Mouffe, 2007: 2). Isto é talanoa adaptado para a batalha oceânica contemporânea.

John's talanoa teaches us something about the state of limbo that treads cautiously between 'ofa fe' unga (compassion and generosity) "to the point of there being nothing left to give away"72 and an adversarial politics where public space is a battleground of different social powers. These battlefields address a myriad of hegemonic histories and stories involving Māori and pākehā, Māori and Moana Nui peoples, Moana Nui and pākehā, the constitution of The Kingdom of Tonga, and, not least, every person's right to own a safe, warm place to live.

The kind of talanoa advocated in these co-operative social artworks might find moments of profound reconciliation with individuals and collectives, like 'Uhila's conversation with 'another' homeless person and John's fleeting conversation on a local bus in Hawaii about landownership. We are serious about challenging the academia in ways of researching that originate from the nga wairua (spirits) and whenua (land) of all peoples. This is an antagonism that tries to combine 'ofa fe' unga with a political dimension that affronts racism, patriarchy and neoliberalism in their inability to grasp the pluralistic nature of the social world. ${ }^{73}$ This is talanoa adapted for contemporary oceanic battle. 
1 Termo utilizado, em Aotearoa para designar os migrantes (e seus descendentes) vindos da região do Pacífico: Cook Islands Tonga, Niue, Samoa, Tuvalu, Tokelau. 2 na lingua Māori, é a designação de Nova Zelândia

3 Por John Vea. Vea retornou em Tonga pela primeira vez em 1995

4 História de um MNak candidato ao PhD compartilhada com John Vea at AUT University, 2 maio, 2018.

5 Cf. Miss Emilia Nixon's "Garden of Memories", Uxbridge Rd, Howick; 110079

http://www.nzmuseums.co.nz/account/3000/object/43719/miss-emilia-nixons-garden-of-memories-uxbridge-rd-howick

6 Taini Drummond com pergunta de John Vea, durante sua palestra como parte de One Kiosk Many Exchanges no Emilia Maud Nixon Garden of Memories in Howick, Auckland, 8, outubro, 2016

7 História por John Vea, 8 outubro, 2016. 8 História por John Vea, 8 outubro, 2016. 9 06/07/2016 3:34PM chat no Facebook Messenger com Jimmy Wulf.

10 Conversa entre John Vea e um local no onibus da University of Hawaii para Chinatown, Honolulu, 30 Junho, 2016.

11 História por Imaikalani Kalahele, ativis- ta, poeta e artista, 29 Junho, 2016. Kalihi Valley, Hawaii.

12 Conversa entre John Vea, Cheryse Sana e Kamuela Enos at Ma'o Farms, Waianae, Hawaii, 6 Julho 2016.

13 História por John Vea, 8 outubro, 2016.

14 História por John Vea, 8 outubro 2016

15 Timote M. Vaioleti, "Talanoa Resear-

ch Methodology: A developing position on Pacific Research", Waikato Journal of Education (2006): 32. https://researchcommons.waikato.ac.nz/bitstream/handle/10289/6199/Vaioleti\%20Talanoa.pdf.

16 Ibid., 32.

17 Chantel Mouffe, "Artistic Activism and Agonistic Spaces". Art and Research: A journal of Ideas Context and Methods 1, no. 2 (2007): 3. http://www.artandresearch.org. uk/v1n2/pdfs/mouffe.pdf.

18 Ibid. 3

19 Ibid., 3,5.

20 Story by John Vea. He attended Panmure District Primary School from 1990-1997. 21 Anne-Marie Tupuola, "Pasifika edgewalkers: complicating the achieved identity status in youth research", Journal of Intercultural Studies 25, no. 1, (2004): https:// doi.org/10.1080/07256860410001687045. 22 lbid.
23 Story by John Vea. He returned to Tonga for the first time in 1995.

24 Vaioleti, Talanoa Research Methodology, 21, emphasis added.

25 Ibid., 32.

26 Ibid., 23.

27 Ibid., 23.

28 Ibid., 23.

29 Ibid., 24.

30 Ibid., 24.

31 Story of a MNak PhD candidate shared with John Vea at AUT University, 2 May 2018.

32 Vaioleti, Talanoa Research Methodology, 25.

33 Amelia Jones, Body Art/performing the Subject (Minneapolis: University of Minnesota Press, 1998), 9.

34 See Christopher Braddock, Performing Contagious Bodies: Ritual Participation in Contemporary Art (London: Palgrave Macmillan, 2013), 17-18.

35 Vaioleti, Talanoa Research Methodology, 26.

36 Ibid., 22

37 Ibid., 30.

38 Ibid., 31 .

39 lbid., 31. 


\begin{tabular}{|c|c|c|}
\hline 40 See Miss Emilia Nixon's “Garden of Me- & 2013, accessed March 25, 2015, http:// & 59 Ibid., 2. \\
\hline mories", Uxbridge Rd, Howick; 110079 & www.artspace.org.nz/exhibitions/2013/ & 60 Ibid., 2. \\
\hline http://www.nzmuseums.co.nz/ac- & jorgesatorre.asp. & 61 Ibid., 2. \\
\hline count/3000/object/43719/miss-emilia- & $46 \mathrm{lbid}$. & 62 lbid., 3. \\
\hline -nixons-garden-of-memories-uxbridge-rd- & 47 Story by John Vea, 8 October 2016. & 63 Ibid., 4. \\
\hline -howick & 48 Tupuola, Pasifika Edgewalkers. & 64 Ibid., 3. \\
\hline 41 Taini Drummond with question by John & 49 06/07/2016 3:34PM facebook messen- & 65 Ibid., 4. \\
\hline Vea, during her talk as part of One Kiosk & ger chat with Jimmy Wulf. & 66 Ibid., 4. \\
\hline Many Exchanges at the Emilia Maud Nixon & 50 Story by John Vea, 8 December 2017. & 67 Ibid., 5. \\
\hline Garden of Memories in Howick, Auckland, 8 & 51 Story by Imaikalani Kalahele, activist, & 68 Ibid., 5. \\
\hline October 2016. & poet and artist, 29 June 2016. Kalihi Valley, & 69 See Bruce E. Phillips, “Discussing Mo'ui \\
\hline 42 Dawn raids were a common event in $\mathrm{Au}$ - & Hawaii. & Tukuhausia: Bruce E Phillips interviews \\
\hline ckland during a crackdown on illegal 'overs- & 52 A conversation between John Vea and & Kalisolaite "Uhila." What do you mean, we?, \\
\hline tayers' from the Pacific Islands from the mi- & a local on the bus from the & edited by B. E. Phillips \& R. Lal, 47-53. Au- \\
\hline d-1970s to the early 1980 s. The raids were & Hawaii towards Chinatown, Honolulu, 30 & ckland: Te Tuhi Centre, 2012. \\
\hline first introduced in 1973 by Norman Kirk's & June 2016. & 70 Bruce E. Phillips, "Curator's response: \\
\hline Labour government and were continued by & 53 Conversation between John Vea, Chery- & Kalisolaite 'Uhila's Mo'ui Tukuhausia" OU- \\
\hline Rob Muldoon's National government. & se Sana and Kamuela Enos at Ma'o Farms, & TPOST: \\
\hline 43 "This east Auckland suburb." New & Waianae, Hawaii, 6 July 20 & Blogs from staff and friends of Auckland Art \\
\hline Zealand History: Nga Korero a Ipurangi a & 54 Story by John Vea, 8 October 2016. & Gallery Toi o Tāmaki, 2014, accessed June \\
\hline Aotearoa, accessed June 1, 2018, https:// & 55 Mouffe, Artistic Activism and Agonistic & 1, 2018, http://aucklandartgallery.blogspot. \\
\hline nzhistory.govt.nz/keyword/howick. & Spaces, 4 & com/2014/08/curators-response-kalisolai- \\
\hline 44 Story by John Vea, 8 October 2016. & $56 \mathrm{lbid} ., 3,5$. & te-uhilas.html. \\
\hline 45 Claudia Arozqueta and Caterina Riva. & 57 Ibid., 2. & 71 Mouffe, Artistic Activism and Agonistic \\
\hline "Jorge Satorre, Emic Etic?" ARTSPACE, & 58 Ibid., 2. & 3,5 . \\
\hline
\end{tabular}

\section{Referências}

Arozqueta, C., \& Riva, C. (2013). Jorge Satorre, Emic Etic. Retrieved from http://www.artspace.org.nz/ exhibitions/2013/jorgesatorre.asp

Braddock, C. (2013). Performing Contagious Bodies: Ritual Participation in Contemporary Art. London: Palgrave Macmillan.

Jones, A. (1998). Body Art: Performing the Subject. Minneapolis: University of Minnesota Press.

Mouffe, C. (2007). Artistic Activism and Agonistic Spaces. Art \& Research: A Journal of Ideas, Contexts and Methods, 1(2), 1-5. http://www.artandresearch.org. uk/v1n2/pdfs/mouffe.pdf

\section{Bibliography}

Arozqueta, Claudia, and Caterina Riva. "Jorge Satorre Emic Etic?” ARTSPACE. 2013. Accessed March 25, 2015. http://www.artspace.org.nz/exhibitions/2013/ jorgesatorre.asp.

Braddock, Christopher. Performing Contagious Bodies: Ritual Participation in Contemporary Art. London: Palgrave Macmillan, 2013.

Jones, Amelia. Body Art - Performing the Subject. Minneapolis: University of Minnesota Press, 1998.

Mouffe, Chantal. "Artistic Activism and Agonistic Spaces." Art and Research: A Journal of Ideas Context and Methods 1, no. 2 (2007): 1-5. http://www.artandresearch.org.uk/v1n2/pdfs/mouffe.pdf. 
Phillips, B. E. (2012). Discussing Mo'ui Tukuhausia: Bruce E Phillips interviews Kalisolaite 'Uhila. In B. E. Phillips \& R. Lal (Eds.), What do you mean, we? (pp. 47-53). Auckland: Te Tuhi Centre.

Phillips, B. E. (2014). Curator's response: Kalisolaite 'Uhila's Mo'ui Tukuhausia. Outpost: Blogs from staff and friends of Auckland Art Gallery Toi o Tāmaki. Retrieved from http://aucklandartgallery.blogspot.com/2014/08/curators-response-kalisolaite-uhilas.html

Phillips, B. E. (2016). Share/Cheat/Unite. Te Tuhi. Retrieved from http://www.tetuhi.org.nz/whats-on/ exhibitiondetails.php?id=171

This east Auckland suburb. (2018). New Zealand History Nga korero a ipurangi a Aotearoa. Retrieved from https://nzhistory.govt.nz/keyword/howick Tupuola, A. M. (2004). Pasifika Edgewalkers: Complicating the achieved identity status in youth research. Journal of Intercultural Studies, 25(1), 87-100. Published online: 22 Jan 2007. Retrieved from https://doi. org/10.1080/07256860410001687045

Vaioleti, T. (2006). Talanoa Research Methodology: A Developing Position on Pacific Research. Waikato Journal of Education, 12, 21-34.
Phillips, Bruce. E. “Discussing Mo'ui Tukuhausia: Bruce E Phillips interviews Kalisolaite "Uhila." What do you mean, we?, edited by B. E. Phillips \& R. Lal, 4753. Auckland: Te Tuhi Centre, 2012. Accessed July 5, 2015. https://bruceephillips.com/writing/discussing-moui-tukuhausia.

Phillips, Bruce E. "Curator's Response: Kalisolaite 'Uhila's Mo'ui Tukuhausia." OUTPOST: Blogs from Staff and Friends of Auckland Art Gallery Toi O Tāmaki (blog), August 24, 2014. Accessed June 1, 2018. http://aucklandartgallery.blogspot.com/2014/08/ curators-response-kalisolaite-uhilas.html.

Phillips, Bruce E. "Share/Cheat/Unite." Te Tuhi. 2016. http://www.tetuhi.org.nz/whats-on/exhibitiondetails.php?id=171.

“This east Auckland suburb." New Zealand History: Nga Korero a Ipurangi a Aotearoa. 2018. Accessed June 1, 2018. https://nzhistory.govt.nz/keyword/ howick.

Tupuola, Anne-Marie. "Pasifika Edgewalkers: Complicating the Achieved Identity Status in Youth Research." Journal of Intercultural Studies 25, no. 1 (2004): 87-100. doi:10.1080/07256860410001687045.

Vaioleti, Timote M. “Talanoa Research Methodology: A Developing Position on Pacific Research." Waikato Journal of Education, 12. (2006): 21-34. https:// researchcommons.waikato.ac.nz/bitstream/handle/10289/6199/Vaioleti\%20Talanoa.pdf. 